\title{
Treatment of trichomonal vaginitis with a single oral dose of metronidazole
}

\author{
K. R. WOODCOCK \\ St. Mary's Hospital, London, W.2
}

One method of overcoming the discrepancy between treatment prescribed and that actually taken is to give a single dose, the taking of which can be observed by the prescribing doctor. This paper reports the results of a trial to investigate the possibility of using single doses of metronidazole in the treatment of Trichomonas vaginalis infections in women.

\section{Methods}

The patients taking part in the trial were attending the St. Mary's Hospital Special Clinic, and were diagnosed by routine darkfield microscopy of the vaginal secretions as having vaginal trichomoniasis. When cervical cytology was investigated this often confirmed the diagnosis, but cytology reports were not used as a diagnostic criterion nor as a test of cure. Cultural methods were not used because previous experience of their use in this Clinic had revealed them to be not substantially more reliable or more sensitive than simple microscopy. Patients were included in the trial when the diagnosis was made while the doctor conducting the trial was on duty. The only patients excluded were those who had already been treated for a trichomonal infection in the previous 3 months.

The treatment used was a single oral dose of $2 \mathrm{~g}$. metronidazole. In the pilot study this necessitated the ingestion of ten tablets, which the patients found some-

Presented to the M.S.S.V.D. at Lyon on May 7, 1971

Received for publication June 7, 1971 what tedious. Subsequently May and Baker were able to supply $400 \mathrm{mg}$. tablets that are only slightly larger than the original $200 \mathrm{mg}$. size. The tablets were taken under supervision and the patients were asked to return in one week and again after one month for repeat tests; further visits were made at the discretion of the patient, but an interval of at least 3 months elapsed in the case of each patient before the results were reviewed.

The criteria for diagnosis and tests of cure, although quite satisfactory for routine clinic work, might be judged insufficient for a scientific study, and so it was decided to establish a control group by the same criteria but employing the standard course of metronidazole $200 \mathrm{mg}$. three times daily for 7 days. Use of a control group lessened the difficulty of establishing whether a recurrence of trichomoniasis was due to treatment failure or to re-infection, because the results were to be judged relatively rather than considered in terms of absolute success or failure. Furthermore results would be applicable to the ordinary routine of this particular clinic. The patients included in the control group were those in whom the initial diagnosis was made at a time when the doctor conducting the trial was not on duty. Again, the only cases excluded were those in patients who had already been treated for trichomonal infection in the previous 3 months.

\section{Case material}

The preliminary data on the trial and control patients are shown in Tables I and II.

TABLE I Concurrent diagnoses in control and trial groups of patients with trichomoniasis

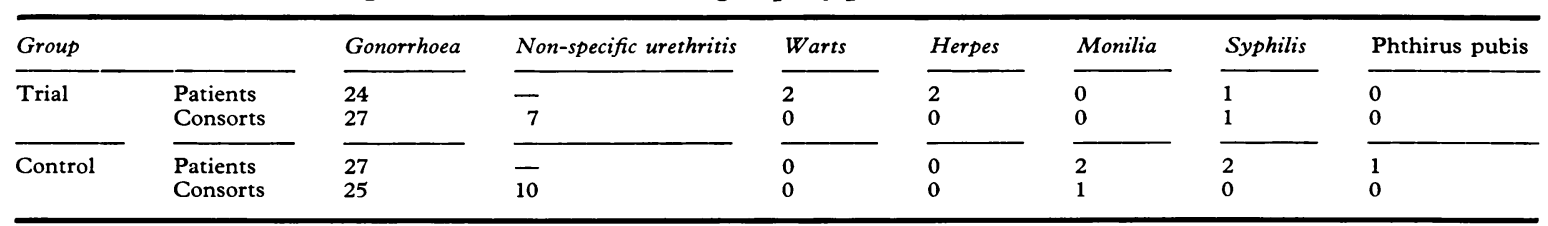

TABLE II Marital status and oral contraceptive therapy in control and trial groups of patients with trichomoniasis

\begin{tabular}{|c|c|c|c|c|c|}
\hline \multirow[b]{2}{*}{ Group } & & \multicolumn{4}{|c|}{ Use of contraceptives } \\
\hline & & On 'pill' & Not on 'pill' & Not recorded & Total \\
\hline Trial & $\begin{array}{l}\text { Married } \\
\text { Single }\end{array}$ & $\begin{array}{r}3 \\
28\end{array}$ & $\begin{array}{l}10 \\
55\end{array}$ & $\begin{array}{l}0 \\
6\end{array}$ & $\begin{array}{l}13 \\
89\end{array}$ \\
\hline Control & $\begin{array}{l}\text { Married } \\
\text { Single }\end{array}$ & $\begin{array}{r}3 \\
25\end{array}$ & $\begin{array}{l}17 \\
52\end{array}$ & $\begin{array}{l}0 \\
4\end{array}$ & $\begin{array}{l}20 \\
81\end{array}$ \\
\hline
\end{tabular}


In the trial group of 102 patients the average age was $24 \cdot 1$ years; 13 per cent. were married; 31 per cent. were taking oral contraceptive tablets. 24 of the patients and 27 of the consorts were diagnosed as having gonorrhoea; seven of the consorts had non-specific urethritis; and a total of six other diagnoses were made, namely two each of warts, herpes, and syphilis.

In the control group of 101 patients the average age was $27 \cdot 1$ years; 20 per cent. were married; 28 per cent. were taking oral contraceptives. 27 of the patients and 25 of the consorts were diagnosed as having gonorrhoea; 10 of the consorts had non-specific urethritis; and there were six other diagnoses made, three of candida, two of syphilis, and one of Phthirus pubis infestation.

It was found in combining the totals for both groups that 53 out of 160 ( 33 per cent.) unmarried patients were taking oral contraceptives as against only six out of 33 (18 per cent.) of married patients.

Table III shows the results obtained by cytological examination in both groups of patients and in those patients with and without gonorrhoea. There was no evidence of malignancy in any patient.

76 per cent. of controls and 81 per cent. of trial patients were examined cytologically. Of those tested, 74 per cent. of specimens from the trial patients and 62 per cent. from controls were reported as positive for trichomonads. Taking both groups together, 73.5 per cent. of the patients without gonorrhoea had positive results for Trichomonas vaginalis, whilst in only 52 per cent. of the patients with gonorrhoea was the trichomonal infection confirmed by cytology.

\section{Results}

The main results are shown in Table IV.

In the trial group of 102 patients, 73 returned for follow-up tests. After 4 weeks there had been nine recurrences of trichomoniasis, representing $12 \cdot 3$ per cent. of those followed. Only one further case of recurrence was revealed by later visits, bringing the final total to ten (13.7 per cent.) of those followed.

In the control group of 101 patients sixty returned for follow-up tests. After 4 weeks there had been four recurrences, representing 6.7 per cent. of those followed, but later visits revealed a further five recurrences, bringing the final total to nine (15 per cent.) of those followed.

Thus, although the early results showed about twice as many recurrences in the trial group as in the control group, the final figures for recurrences showed essentially the same proportion in both groups. And even if one chooses to ignore the later recurrences in the control group, it will be seen that most of the extra failures with the $2 \mathrm{~g}$. dose occurred within the first week, and therefore caused very little inconvenience. The possibility that these early failures might, paradoxically, have been of benefit to the patients is discussed below.

\section{RELATIONSHIP OF RECURRENCES TO GONORRHOEA}

Table V (opposite) shows that, in the control group, six of the nine cases of recurrence $(66.7$ per cent.) were not associated with gonorrhoea at any time. This figure accords well with the cumulative figures for both groups-of the 203 patients involved, 141 (70 per cent.) were found not to have gonorrhoea. Yet, of the ten patients with recurrences in the trial group, only two (20 per cent.) did not have gonorrhoea diagnosed at any time, and in five of the eight with gonorrhoea it was not diagnosed on the first visit.

TABLE II I Cervical cytology in control and trial groups of patients with trichomoniasis with and without gonorrhoea

\begin{tabular}{ll} 
Group & \\
\hline Trial & $\begin{array}{l}\text { Gonorrhoea present } \\
\text { Gonorrhoea absent }\end{array}$ \\
\hline Control & $\begin{array}{l}\text { Gonorrhoea present } \\
\text { Gonorrhoea absent }\end{array}$
\end{tabular}

\begin{tabular}{|c|c|c|c|}
\hline T. vag. positive & T. vag. negative & Not tested & Total \\
\hline $\begin{array}{r}9 \\
51\end{array}$ & $\begin{array}{r}8 \\
13\end{array}$ & $\begin{array}{r}7 \\
14\end{array}$ & $\begin{array}{l}24 \\
78\end{array}$ \\
\hline $\begin{array}{l}12 \\
35\end{array}$ & $\begin{array}{l}11 \\
18\end{array}$ & $\begin{array}{r}4 \\
21\end{array}$ & $\begin{array}{l}27 \\
74\end{array}$ \\
\hline
\end{tabular}

TABLE IV Follow-up and results in control and trial groups

\begin{tabular}{lll}
\hline Length of follow-up (wks) & & \\
\hline Total cases & $\begin{array}{l}\text { Control } \\
\text { Trial }\end{array}$ \\
\hline Recurrence of $T$. vaginalis & No & $\begin{array}{l}\text { Control } \\
\text { Trial }\end{array}$ \\
\cline { 2 - 3 } & Yes & $\begin{array}{l}\text { Control } \\
\text { Trial }\end{array}$ \\
\hline $\begin{array}{l}\text { Cumulative recurrence as } \\
\text { percentage of cases followed }\end{array}$ & $\begin{array}{l}\text { Control } \\
\text { Trial }\end{array}$ \\
\hline
\end{tabular}

$\mathbf{0}$
$\overline{2}$
$\overline{-}$
$\overline{-}$
$\overline{-}$

\begin{tabular}{|c|c|}
\hline$<1$ & $1-4$ \\
\hline $\begin{array}{l}60 \\
73\end{array}$ & $\begin{array}{l}52 \\
60\end{array}$ \\
\hline $\begin{array}{l}8 \\
9\end{array}$ & $\begin{array}{l}21 \\
28\end{array}$ \\
\hline $\begin{array}{l}0 \\
4\end{array}$ & $\begin{array}{l}4 \\
5\end{array}$ \\
\hline 二 & $\begin{array}{r}6 \cdot 7 \\
12 \cdot 3\end{array}$ \\
\hline
\end{tabular}

\begin{tabular}{l}
$\frac{5-8}{27}$ \\
\hline 27 \\
\hline 21 \\
\hline 2 \\
\hline
\end{tabular}

\begin{tabular}{|c|c|c|}
\hline $9-12$ & $12+$ & Total \\
\hline $\begin{array}{r}12 \\
6\end{array}$ & $\begin{array}{l}3 \\
2\end{array}$ & $\begin{array}{l}101 \\
102\end{array}$ \\
\hline $\begin{array}{l}8 \\
4\end{array}$ & $\begin{array}{l}1 \\
1\end{array}$ & $\begin{array}{l}51 \\
63\end{array}$ \\
\hline $\begin{array}{l}1 \\
0\end{array}$ & $\begin{array}{l}2 \\
1\end{array}$ & $\begin{array}{r}9 \\
10\end{array}$ \\
\hline $\begin{array}{l}11 \cdot 7 \\
12 \cdot 3\end{array}$ & & $\begin{array}{l}15.0 \\
13.7\end{array}$ \\
\hline
\end{tabular}


TABLE V Relationship of gonorrhoea to recurrences in control and trial groups of patients treated for trichomoniasis

\begin{tabular}{|c|c|c|c|}
\hline \multirow[b]{2}{*}{ Group } & \multicolumn{3}{|l|}{ Gonorrhoea } \\
\hline & Diagnosed initially & Diagnosed later & Not diagnosed \\
\hline Control & 2 & 1 & 6 \\
\hline Trial & 3 & 5 & 2 \\
\hline
\end{tabular}

The trial was not designed to investigate any relationship with gonorrhoea and it is possible to envisage several factors which may have artifically influenced these findings. Nevertheless, it suggests that a failure to respond to a $2 \mathrm{~g}$. dose of metronidazole might indicate the need for extra alertness to possible underlying gonococcal infection.

RELATIONSHIP OF RECURRENCES TO CONSORT TREATMENT No attempt was made to assess the adequacy of treatment of consorts, and it was hoped that any reinfections would be evenly distributed between the two groups. However, the preponderance of late recurrences in the control group might suggest that an even distribution had not occurred.

A further complication arose because four of the consorts of patients in the trial group were inadvertently treated with a $2 \mathrm{~g}$. dose instead of the intended $200 \mathrm{mg}$. three times a day, and three of the four patients concerned were amongst the ten with recurrences. The main purpose of referring to them here is to point out that whereas a single $2 \mathrm{~g}$. dose appears to offer satisfactory therapy in women, it does not follow that it will be satisfactory for their consorts.

\section{SIDE-EFFECTS}

The incidence of side-effects was based on spontaneous complaints; there were no direct enquiries. Three patients had considerable difficulty in swallowing the five tablets, but none failed to take them; each of them confessed to great difficulty in swallowing any tablets at any time, and it might be supposed that these are the ones who would benefit most from supervised therapy. Four patients complained of feeling slightly sick for from 6 to 48 hours after therapy, but none of these vomited. One patient complained of headache, nausea, vomiting, and general malaise, but, she explained, these symptom occurred whenever she took any type of tablet!

\section{SERUM LEVELS OF METRONIDAZOLE}

At least three cases of attempted suicide involving metronidazole have been reported. In one (Fluker, 1961), a dose of 4.2 g., and in the other two (Lewis and Kenna, 1965) doses of 3.6 and $12 \mathrm{~g}$. were taken with no serious consequences; unfortunately serum levels were not obtained in these patients. Kane, McFadzean, Squires, King, and Nicol (1961) reported blood levels in two patients taking metronidazole $200 \mathrm{mg}$. three times a day for 7 days. These are shown graphically in the Figure with the serum levels from six volunteers in the present series who took a single $2 \mathrm{~g}$. dose.

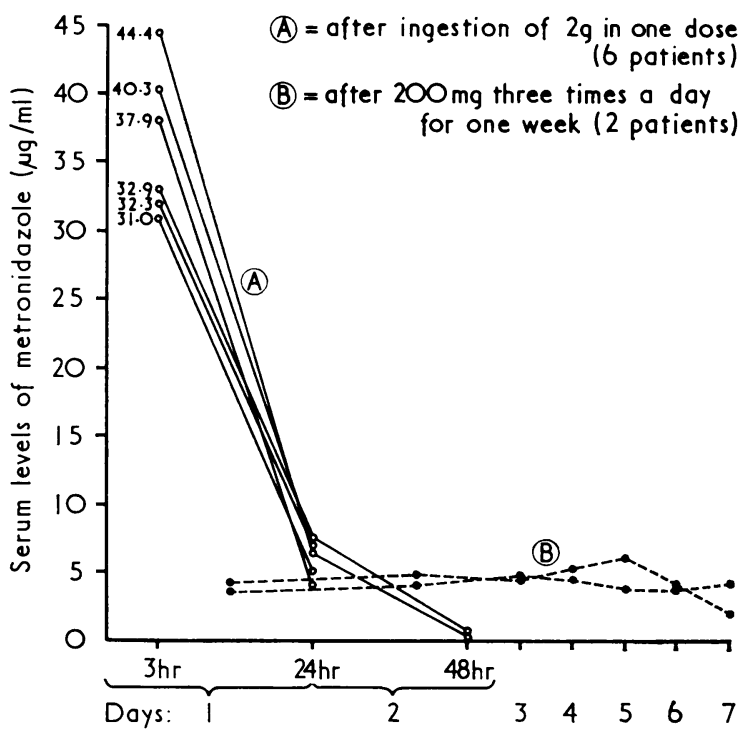

FIGURE Serum levels of metronidazole

It will be seen that the standard dose produced serum levels of 4-5 $\mu \mathrm{g}$. $/ \mathrm{ml}$. during the period of therapy. After the $2 \mathrm{~g}$. dose, high levels of 30-45 $\mu \mathrm{g} . / \mathrm{ml}$. were found after $3 \mathrm{hrs}$., and levels of 4-7.5 $\mu \mathrm{g} . / \mathrm{ml}$. after $24 \mathrm{hrs}$; the two levels that were obtained after $48 \mathrm{hrs}$. were 0.5 and $0.7 \mu \mathrm{g} . / \mathrm{ml}$.

Testing in vitro has revealed that most strains are sensitive to levels of $0 \cdot 25-0 \cdot 125 \mu \mathrm{g} . / \mathrm{ml}$. (Jennison Stenton, and Watt, 1961). Thus, the $2 \mathrm{~g}$. dose gave trichomonicidal levels for at least $24 \mathrm{hrs}$. and possibly for $48 \mathrm{hrs}$., and produced up to 30 to 40 times the trichomonicidal level shortly after administration.

\section{Discussion}

The introduction of metronidazole in 1959 transformed the management of trichomoniasis. Success rates with earlier treatments ranging from 30 per cent. (Pearson, 1957) down to 0 per cent. (Willcox, 1957) were replaced by reports of 86 per cent. (Rodin, 
King, Nicol, and Barrow, 1960), 95 per cent. (Willcox, 1960), and even 100 per cent. success (Keighley, 1962).

The high therapeutic index (Cosar and Julou, 1959) and the rapid excretion rate (Kane and others, 1961) make metronidazole a very safe drug, and the trial reported here shows that it is certainly effective in large single doses. No adverse effects have been reported with its use in pregnant women (Perl, 1965; Peterson, Hansen, Stauch, and Ryder, 1966; ScottGray, 1964) but, in view of the very high serum levels involved, it would seem unwise, at the present time, to use the single dose treatment during pregnancy.

A surprise finding was an apparent relationship between the failure of the $2 \mathrm{~g}$. dose to eradicate trichomonads in the presence of undetected gonorrhoea. However, the trial was not designed to elicit such a finding, and no conclusions have been drawn. Nicol, Evans, McFadzean, and Squires (1966) reported one case of trichomoniasis in which an organism of the genus Mimae interfered with treatment by locally inactivating the metronidazole. No other firm evidence appears in the literature concerning the relationship of other organisms to cases of recurrent trichomoniasis.

The recurrence rates of 13.7 and 15 per cent. should not be considered in isolation. It must be emphasized that no attempt was made to assess whether the consorts were treated adequately; and the total follow-up period was longer than 3 months, leaving plenty of time for re-infections to have occurred. The important finding in this trial was that the difference between the results in the two groups was not of significance and that the treatment of trichomoniasis in women with single doses of $2 \mathrm{~g}$. metronidazole appears to be a satisfactory regime.

\section{Summary}

102 women with vaginal trichomoniasis were each treated with a single oral dose of $2 \mathrm{~g}$. metronidazole. In a control group of 101 cases treatment was by $200 \mathrm{mg}$. metronidazole three times daily for 7 days. Recurrence rates in those followed up were ten of 73 (14 per cent.) and nine of sixty (15 per cent.) respectively. Most recurrences in the trial group were in the first month (four in the first week), whereas in the control group half the recurrences were in the 4th to 12th week period. There was an apparent relationship between failure with the $2 \mathrm{~g}$. dose and the presence of gonorrhoea, undetected at the time. Side-effects were limited to nausea in four cases and vomiting in one. It was concluded that the single oral dose of $2 \mathrm{~g}$. was an acceptable treatment for vaginal trichomoniasis.

Thanks are due to Dr. F. J. G. Jefferiss and Dr. R. R. Willcox for allowing me to conduct the trial on patients under their care; to the May and Baker Laboratories for estimating the serum levels of metronidazole; and to Miss C. N. Reynolds for her help in preparing the text.

References

Cosar, C., and Julou, L. (1959) Ann. Inst. Pastzur, 96, 238

FlukER, J. L. (1961) Brit. f. vener. Dis., 37, 280

Jennison, R. F., Stenton, P., and Watt, L. (1961) f. clin. Path., 14, 431

Kane, P. O., McFadzean, J. A., Squires, S., King, A. J., and Nicol, C. S. (1961) Brit. F. vener. Dis., 37, 723

KeighLEY, E. E. (1962) Brit. med. F., 2, 93

Lewis, B. V., and KeNNA, A. P. (1965) f. Obstet. Gynaec. Brit. Cwlth, 72, 806

Nicol, C. S., Evans, A. J., McFadzean, J. A., and SQuIRES, S. L. (1966) Lancet, 2, 441

Pearson, A. C. (1957) F. Obstet. Gynaec. Brit. Cwlth, 64, 436

PerL, G. (1965) Obstet. and Gynec., 25, 273

Peterson, W. F., Hansen, F. W., Stauch, J. E., and Ryder, C. D. (1967) Amer. F. Obstet. Gynec., 97, 472

Rodin, P., King, A. J., Nicol, C. S., and Barrow, J. (1960) Brit. F. vener. Dis., 36, 147

Scott-Gray, M. (1964) f. Obstet. Gynaec. Bit. Cwlth, 71,82

Willcox, R. R. (1957) Brit. F. vener. Dis., 33, 115 (1960) Ibid., 36, 175

Traitement de la vaginite à Trichomonas par une dose orale unique de métronidazole

SOMMAIRE

102 femmes atteintes de vaginite à Trichomonas reçurent chacune une dose unique orale de $2 \mathrm{~g}$. de métronidazole. En tant que groupe témoin, 101 autres cas furent traités par $200 \mathrm{mg}$. de métronidazole trois fois par jour pendant 7 jours. Chez les femmes revenues pour contrôle, le TV reparut dans 10 cas sur 73 (14 pour cent) dans le premier groupe et dans 9 cas sur 60 (15 pour cent) dans le second. La plupart des rechutes dans le groupe d'essai survinrent au cours du premier mois (quatre lors de la première semaine) alors que, dans le groupe témoin, la moitié des rechutes furent observées entre la 4ème et la 12ème semaine. Il y eut une relation apparente entre les échecs à la dose de $2 \mathrm{~g}$. et la présence d'une gonococcie, non decouverte au départ. Les effets secondaires furent limités à 4 cas de nausée et 1 de vomissement. On conclut qu'une dose unique orale de $2 \mathrm{~g}$. a constitué un traitement approprié pour la vaginite à Trichomonas. 